\title{
"At sætte lethed ind mod tyngde" \\ - offentlighed, islam og politik i forlangelse af De sataniske vers.
}

"Fjorten Dage senere samles den synlige Læseverden (thi der er Forskjel som mellem den synlige og usynlige Kirke) igjen i Synagogen. Man begynder, hvor man slap. "Har De læst den fortræffelige Recension?" Nei. "Da maa De læse den. De maa endeligen læse den; den er aldeles som jeg selv kunde have skrevet den." - "Mærkeligt nok, det Samme som den interessante Recensent siger, var det jeg sagde, blot jeg havde bladret i Bogen inde hos Reitzel." - "Jeg har endnu ikke læst den, men jeg har hørt fra en Ven paa Landet, der sku er et godt Hoved og Kjender, at Bogen er forfeilet; om der end er ret skjønne Steder deri." Hermed hænger det saaledes sammen. Hiin Ven paa Landet har ikke læst Bogen, men faaet Brev fra en Mand i Hovedstaden, der heller ei har læst Bogen, men læst Anmeldelsen, som igjen var skrevet af en Mand, der ikke havde last Bogen, men hørt, hvad hiin paalidelige Mand sagde, der havde bladret lidt i den hos Reitzel. Summa summarum det er ikke utænkeligt, at en Bog kunde udkomme, vække Sensation, foranledige en Recension, der blev læst, medens Bogen ligesaa godt kunde være uskreven, eller i det høieste ligesaa kort affattet som hiint første lilbuds Efterretning. Naar blot Snakken kan komme i Bevægelse, saa er alt godt. Og skulde den ikke kunne komme i Gang? Det maatte være en besynderlig Bog. Intet er saa galt, at det jo er godt for Nogen, og intet saa godt, at det jo er galt for Nogen"

Søren Kierkegaard

\section{Indledning: "All that is solid melts into air"}

I den moderne vestlige verden har begivenheder det med hurtigt at blive en del af vores fælles fortids historie - og dermed kedelige og uinteressante for andre end dem, der lever af at interessere sig for tiden før nu. Fra et mediesynspunkt var det således også heldigt, at amerikanerne var så effektive i deres nedkæmpelse af Irak i den nyligt overståede krig om Kuwait. Var krigen trukket ud, ville medierne have haft svært ved fortsat at skulle dække den - folk ville simpelthen have mistet interessen. Heldigvis for såvel medier som for mere direkte involverede personer gik det ikke sådan: Krigen blev hurtigt overstået, og medieme kunne kaste sig over andre og først og fremmest nye begivenheder som f.eks. borgerkrigen i Jugoslavien.

Når interessen for begivenheder hurtigt svækkes, hænger det sammen med et ganske særligt træk ved det moderne informationssamfund: nemlig at in- 
formationsdækning ikke primært handler om formidling af information, men om måden, hvorpå formidlingen sker. Indholdet i tv er ikke, som man måske skulle tro, den viden, der formidles, men tv: "The medium is the message" som det slagordsagtigt blev formuleret af Marshall McLuhan i 60'erne. Dette gjorde sig tydeligt gældende i DRs dækning af Kuwaitkrigen, der mere handlede om, hvordan DR etablerede nye fortælleformer, ændrede tv-studiets indretning osv. alt sammen tydeligt inspireret af det amerikanske CNN. Budskabet fra Gyngemosen og Jens Nauntofte var egentlig mere "se, hvor godt vi dækker konflikten" (og heldigvis for DR og TV-avisen steg seertallet voldsomt under forløbet) end det handlede om, hvad der skete. Dette være ikke sagt med en løftet pegefinger til DR, der blot i sådanne sager handler som alle andre medier gør det. DR er blot trukket frem som et eksempel på tingenes tilstand. En tilstand, der alt efter temperament og politisk ståsted kan tiljubles eller begræedes.

Hensigten her er ikke at analysere mediemes dækning af konflikter eller kritisere nyhedsdækningen for den manglede interesse i de nyheder, den dækker. Men at medierne primært handler om medier får nogle konsekvenser, hvoraf to skal nævnes her. For det første er det nødvendigt, når man som her vil beskæftige sig med Rushsdie-sagen, der jo udspillede sig for flere år siden (!), at begrunde, hvorfor man endnu kan finde denne sag interessant. Nyheder rummer deres egen begrundelse, nemlig at de er nye. Så er det egentlig lige meget om nyheden handler om, at Janni Spies er blevet haste-indlagt eller om, at Sovjetunionen er ved at gå i opløsning - blot det sker nu ("Køb BT - så sker der noget"). Selv sad jeg fastklæbet til skærmen og så på CNN, hvordan Kuwaitkrigen startede. Bagefter undrede jeg mig lidt over, om jeg var bedre informeret end mine venner, der først hørte om krigsudbruddet i radioen dagen efter. I hvert fald bildte jeg mig ind at kunne udtale mig med lidt større vægt - mærkeligt, ikke? Det korte af det lange er dog, at enhver beskæftigelse med en begivenhed, der ikke udspiller sig nu, kræver en forklaring. Det andet forhold, jeg vil pege på, er at den hurtige omsættelighed mellem begivenhed og beretning forudsætter foreliggende mønstre - eller strukturer om man vil - som beretningen kan forløbe i. Skemaer, der ordner og strukturerer begivenhedernes kaos og som forudstrukturerer enhver tale og beretning om den. Det interessante i denne forbindelse er ikke, at beretninger allerede altid er formet af bestemte narrative strukturer - sådan fungerer sprog bare. Det interessante er heller ikke at identificere, hvilken narrativ struktur, som har sat sig i gennem. Om det f.eks. er en eventyrmodel af greimasiansk tilsnit, der dannede mønster for DRs dækning af Kuwaitkrigen. Det interessante er, hvilke metaforer og retoriske troper beretningerne frembringer og hvilke forestillinger om os og de andre, som dermed konsolideres - konkret.

I tilfældet Rushdie blev sagen meget hurtigt til en fabel om vestlig frihed versus orientalsk fanatisme; om vestlig ytringsfrihed kontra islamisk moral; om Madonnas 
"Express your self" over for Khomeinis "hold kæft og adlyd". Denne fabel udspillede sig på baggrund af en bog - en roman - som kun de færreste havde læst, men som de fleste havde en mening om. En mening, der retorisk udfoldede sig på baggrund af den beretning, som medierne, "Iilbudene", tilbød os. Heldigvis er Rushdie-sagen ikke ny længere. Der er gået nogen tid og muligheden for, at andre narrative mønstre har sneget sig ind i tomrummet mellem dengang og nu er tilstede. Hegel havde ret: Det er først i aftenskumringen, at Minervas ugle begynder sin flugt, og det er først nu, hvor Rushdie-sagen har mistet sin nyhedsværdi, at den er blevet interessant.

Det er klart, at dette synspunkt arrogant ser bort fra de direkte involverede personer - først og fremmest Salman Rushdie selv, der den dag i dag må leve skjult. Med al den respekt og medfølelse jeg har for Rushdie, er det dog ikke hans personlige skæbne, jeg i det følgende vil beskæftige mig med - men det fænomen, der meget hurtigt kom til at hedde "Rushdie-sagen".

\section{Hvorfor er Rushdie-sagen interessant?}

På trods af, at nyhedværdien omkring Rushdie-sagen forlængst er væk, har den stadig aktualitet: Mellemøsten ligger tæt på Europas grænser, hvilket betyder, at konflikter i regionen umiddelbart ligger inden for det europæiske interessefelt. Regionen udgør på den ene side et stort marked og er på den anden side rig på energiressourcer. Taget under et er befolkningstilvæksten voldsom, og det pres, der allerede nu er på EFs grænser i form af indvandrere, vil utvivlsomt $\emptyset$ ges i årene fremover. Skønt presset i første omgang især ligger på Italien, Frankrig og Spanien har det på længere sigt konsekvenser for hele EF, og Bruxelles har da også allerede gjort de første tiltag til en middelhavspolitik, der tager sigte på den demografiske udvikling. Om man som europæer og EF-borger kan lide det eller ej, vil fremtiden derfor med uomtvistelig sikkerhed involvere en form for samliv med persere, arabere og nordafrikanere. Inden for de seneste år har i det mindste to begivenheder med al tydelighed demonstreret, at et sådant samliv ikke vil komme til at forløbe gnidningsfrit. Der tænkes selvfølgelig på den konflikt, der udspillede sig efter Iraks invasion af Kuwait og på Rushdie-sagen. Begge konflikter viste, at forskellene mellem muslimsk og vestlig kultur er store - endog meget store. Med udsigten til et kommende økonomisk, politisk og kulturelt samliv, der altså ikke nødvendigvis vil have form af samarbejde, er det nok værd at spekulere lidt over forskellene mellem dem og os.

Det er her Rushdie-sagen viser sin aktualitet: Den udspillede sig på baggrund af noget så trivielt, men samtidigt genuint europæisk som en roman. I sit udgangspunkt var konflikten kulturel, hvor den europæiske kulturs tolerance over for æstetisk 
frihed tørnede sammen med en kultur, hvor æstetikken til enhver tid er underlagt religionen. Dermed muliggør sagen et kulturanalytisk studium af, hvordan muslimsk kultur tolker og opfatter den vestlige verden, og hvordan vesten på sin side tolker denne opfattelse. Det oplagte i sagen i et studium af forskellene mellem muslimsk og vestlig kultur ligger $\mathrm{i}$, at den på engang drejer sig om et begrænset aspekt, nemlig det æstetiske, men samtidigt er den eksemplarisk for kulturforskellene som sådan. Derved er det muligt på baggrund af et relativt overskueligt materiale at få indsigt i generelle træk i såvel muslimsk og vestlig kultur som forskellene mellem dem.

Imidlertid rejser sagen også nogle mere principielle spørgsmål af kulturanalytisk art. Et særligt problem stiller sig allerede i valget af udgangspunkt for analysen. F.eks. kan man mene, at sagens kerne er den parodi på Muhammad og Islam, som De sataniske vers også indeholder. Hermed har man allerede lagt sig fast på en tolkning af konklikten, som til syvende og sidst gør islam til det væsentligste. Analytikeren vil først og fremmest konsultere religionshistoriske værker med henblik på at besvare spørgsmålet om, hvorfor muslimerne følte sig så krænket som de tilsyneladende gjorde. Endvidere vil analysen ofte stadfæste det ganske vist udbredte synspunkt, at religion og politik er helt sammenvævede i muslimske samfund, og at politikken er underlagt islamisk lov, sharia. En sådan analysestrategi har været udbredt i diskussionen af Rushdie-sagen og er blevet anvendt af såvel kritikere som forsvarere af De sataniske vers - som eksempler fra hver sin lejr kan nævnes Malise Ruthven og Mohammad Mehdi. ${ }^{1}$ Der er for mig at se i det mindste to problemer i en sådan strategi: for det første tager den udsagnene om blasfemi og krænkelser som følge af blasfemi for pålydende, og for det andet tenderer analysen til at gøre forskellene mellem orientalsk og occidentalsk kultur til substantielle modsætninger. Imidlertid er der skrevet litteratur både inden for og uden for den muslimske verden, der ikke lader De sataniske vers noget tilbage, hvad blasfemi angår, og hvorfor er der så ikke, må man spørge, blevet en sag ud af denne litteratur? ${ }^{2}$ At gøre forskelle til modsætninger er i denne sammenhæng at reducere kulturelle formationer til fastlåste fiksérbilleder. Kulturelle formationer er for mig at se foranderlige størrelser, hvor f.eks. forhold mellem politik og religion ikke er givet én gang for alle, men afhængig af en lang række omskiftelige forhold: sker der ændringer et sted i formationen, medfører det ændringer et andet sted i den.

På en måde ligner kultur sprog, og kultur er ligeså foranderlig og dynamisk som sprog er det. På denne baggrund er det nok lidet overraskende, at et af de begreber, jeg vil trække frem i min behandling af Rushdie-sagen, er hentet fra sprogteorien, nemlig diskursbegrebet. Nærmere bestemt diskurs sådan som Michel Foucault anvender begrebet i Les mots et les choses fra $1966 .{ }^{3}$ Mindst to bestemmmelser gør sig gældende her: For det første bruges begrebet til at identificere en gruppe af udsagn. Der kan f.eks. være tale om "den videnskabelige diskurs", der sammenfatter den måde videnskaben taler om sine emner og om sig selv på, men som 
endvidere også indbefatter udsagn, der ikke i sig selv er af videnskabelig art, men som vinder sin retoriske overbevisning gennem reference til videnskaben. For det andet er diskurs navnet for den regelstyrede praksis, hvorefter bestemte argumentationer systematiseres og ordnes. En bestemt kulturformation kan derfor undersøges gennem en analyse af dens diskursformer, dvs. måden hvorpå den italesætter f.eks. politiske, religiøse, økonomiske forhold på. Foucaults pointe er, at italesættelsen - diskursen - ikke blot er en tale om, men snarere opfindelsen eller skabelsen af de pågaldende forhold. Dette vil jeg vende tilbage til i forbindelse med en bestemmelse af nationalstaten som en diskursiv formation. Imidlertid skal forholdet mellem diskurs og intention kort berøres. Diskursen er ikke resultat af det bevidste og suveræne subjekts beherskelse, men er snarere udtryk for nogle mønstre, hvori subjektets tale så at sige på forhånd organiseres. Forholdet mellem diskurs og tale er altså analog til forholdet mellem langue og parole hos den schweiziske sprogforsker Ferdinand de Saussure, og endelig kan diskursbegrebet sammenlignes med sprogspilsbegrebet hos Wittgenstein. Der er altså ikke tale om, at diskurserne opfindes af et subjekt eller en gruppe af subjekter med henblik på f.eks. at fordreje nogle kendsgerninger eller skabe nogle bestemte fjendebilleder. Når der her kan være grund til at gøre opmærksom på dette, skyldes det den kritik, der er blevet rettet mod Edward W. Saids bog Orientalism. ${ }^{4}$ I denne bog analyserer Said orientalismen som et anonymt tekstkorpus, der allerede inden studierne af Orienten er strukturerende for dem. Hans hensigt er ikke at analysere de konkrete studier, men den kontekst, som de er blevet til i, og som er styrende for de perspektiver på såvel orienten som vesten, der ligger til grund for studierne. Med andre ord er det, han definerer som orientalisme, bestemt som diskursiv formation, et begreb for de kulturelt bestemte billeder og forestillinger (metaforer) om Orienten, der både er styrende for udviklingen af videnskaben om Orienten, men som denne videnskab på sin side er med til at konsolidere. Kritikken mod Said går på, at han fremstiller orientalisterne som et konspiratorisk vestligt komplot, der bevidst tilrettelægger og producerer bestemte nedværdigende billeder af den arabiske verden. Men da Said bestemmer orientalisme som en narrativ struktur, diskurs, der går forud for den bevidste tale og analyse, er denne kritik forfejlet - hvilket ikke udelukker, at der er mange andre punkter, hvor hans bog med rette bør kritiseres. Endelig skal det tilføjes, at den orientalistiske diskurs selvfølgelig er del af en kontekst, en "større" diskurs, der kan kaldes den europæiske og som eksemplarisk er sammenfattet af den tyske filosof G.W.F. Hegel i hans historiefilosofi. Her anskuer han verdenshistorien som havende en bestemt retning imod Ånd og Frihed. På denne vej tilbagelægger den en række stationer som f.eks. den orientalske, den klassiske, den katolske, og udviklingen (dannelsen) kulminerer i den moderne protestantiske nationalstat. Det er klart, at de stationer, der er tilbagelagt, f.eks. den orientalske, betragtes som værende primitive eller ses på med en form for nostalgisk eksotisme, jvf. forestillingen om 
"den ædle vilde". Princippet i udviklingen er fornuft: rationalitet, og dette princip binder Hegel eksplicit sammen med udviklingen af evnen til at læse og skrive og til det fonetiske alfabet: "Heraf følger, at dette at læse og skrive en alfabetisk skrift må betragtes som et uendeligt dannelsesmiddel, som ikke skattes højt nok; thi ånden, som således fjerner sig fra det konkret sanselige, retter sin opmærksomhed mod det mere formelle moment, det lydlige ord og dets abstrakte elementer, og bidrager væsentligt til at rydde og rense grunden for en inderlighed i subjektet". 5 Forskellen mellem den rationelle europæiske civilisation, sådan som vores tradition har fastlagt den, og andre kulturer kan altså koges ned til en forskel i brugen af sprog samt i måden sprog tilegnes på. Dette er i denne sammenhæng en vigtig pointe, da den konkrete sag udspiller sig om en ganske særlig måde at bruge sprog på: en roman og jeg skal da også vende tilbage til forholdet.

Når begrebet diskurs anvendes i det følgende, er det altså ikke med henblik på en identifikation af særlige skurke, men i et forsøg på at fremdrage nogle af de fortællemønstre, vi næsten med automatik falder ind i, så snart vi vil identificere os selv til forskel fra de andre. Analysen vil tage sit udgangspunkt i en præsentation af bogen $D e$ sataniske vers og fortsætte med en redegørelse for romangenren som et genuint europæisk fænomen, der er sammenfaldende med udviklingen af den moderne nationalstat. Derefter skal forholdet mellem religion og politik diskuteres som baggrund for en analyse af indholdet i "The Rushdie-Affair". Det skal vises, at Rushdie-sagen ikke blot handler om en modsætning mellem Madonnas "Express your self" og Khomeinis "hold kæft og adlyd". Det gør den også, men der er mere end ytringsfrihed på spil. Endelig skal der argumenteres for, at religion i den islamiske verden i høj grad er en retorik i politikkens tjeneste.

\section{Roman: De sataniske vers}

"The novel is the privileged arena where languages in conflict can meet, bringing together in tension and dialogue, not only opposing characters, but also different historical ages, social levels, civilization and other dawning realities of human life."

Carlos Fuentes

I et interview, BBC lavede, beklagede Salman Rushdie sig over, at hans roman var blevet diskuteret $\mathrm{i}$ alle mulige sammenhænge og som udtryk for de forskelligste ting, men ikke som det den er: en roman. Skønt der er kommet litterære essays om bogen, har Rushdie ret, og man forstår hans ærgrelse. Sagen om den har helt overskygget dens status af at være en litterær frembringelse og det i en grad, at mange har afholdt sig fra at læse bogen. Den politiske diskussion omkring bogen forhindrede mere 
eller mindre en litterær reception af den. Det er synd og skam: De, der har gjort sig ulejligheden med at læse bogen, har fået en romanoplevelse ud over det sædvanlige. De sataniske vers er en, hvad litterære kvaliteter angår, helt enestående god bog og jeg tror ikke, der kan være tvivl om, at romanen vil overleve sagen. Men for at føje spot til skade vil også jeg diskutere den mere som et politisk dokument end som en litterær produktion. Inden skal bogen dog kort præsenteres.

Bogens handling samler sig om to hovedpersoner: Gibreel Farishta, en berømt filmstjerne, der især har haft succes i indiske "theologicals", en form for filmiske gendigtninger af religiøse begivenheder, og Saladin Chamcha, oprindeligt Salahuddin Chamchawala, en urban anglofil, der formægter sin fortid i Bombay og som tjener sine penge ved at lægge stemme til tv-reklamer. Deres navne giver umiddelbart associationer: Gibreel Farishta oversættes fra Urdo til Gabriel engel, altså ærkeenglen Gabriel, der i den islamiske tradition bragte Allahs budskab (Koranen) til profeten Muhammad. Saladin er den store hærfører fra den islamiske middelalder, der nedkæmpede de kristne korsfarere, og Chamcha betyder på Urdo noget i retning af "medløber", og ordet konnoterer tillige homoseksualitet. Bogen indledes med, at de to personer, efter at deres Boeing jetfly er blevet spængt i luften over den engelske kyst, falder $10.000 \mathrm{~m}$ ned og på mirakuløs vis overlever og bliver skyllet i land i England. Herefter sker der mærkelige forandringer med dem, og bogen væves i et kompliceret netværk af fortællinger. En del vedrører de to personers baggrund og deres skæbne efter faldet til England, en del udspiller sig i Gibreels drømme, og endelig væves andre parallelhandlinger ind i teksten. I dette netværk af fortællinger lykkes det Rushdie at ironisere over snart sagt enhver form for ideologi: den engelske Thatcher-ideologi, Khomeini, islam, kristendom, marxisme, amerikansk forbrugerisme og meget andet, og på denne måde er et gennemgående tema $\mathrm{i}$ bogen at sætte spørgsmålstegn ved enhver form for overgribende ideologi, hvad enten denne måtte maskere sig som religion, politik eller teori. Dette træk ved bogen hænger snævert sammen med dens hovedtema, som Rushdie selv har kaldt "Bastardkultur". Med Rushdies egne ord: "De sataniske vers hylder hybriditet, urenhed, blanding og den forvandling, der følger af nye og uventede kombinationer af mennesker, kulturer, tanker, politiske ideer, film, sange. Den jubler over bastardiseringen og frygter det Renes absolutisme. Blanding, sammenrod, lidt af dette og lidt af hint, det er på denne måde det nye kommer til verden. Det er den vældige chance, som de store befolkningsflytninger giver verden, og jeg har prøvet at tage den til mig. Romanen er for forandring-ved-sammensmeltning, forandringved-forening. Det er en kærlighedssang til vore bastard-jeg'er". ${ }^{6}$ Dens tema er dermed den bastardkultur, der er - eller måske kan blive - resultatet af befolkningsflytninger, migrationer og mere konkret den kultur, der er under udvikling i England som følge af indvandring. En del af bogens handling finder da også sted i indvandrermiljøer i England, ligesom den skildrer konfrontationer mellem indvandrere og 
englændere, mellem to typer identitet: indvandreren og nationalisten. I sin hyldest til bastardkulturen er bogen og dens forfatter tydelig solidarisk med indvandrerne, herunder de muslimske, og et sigte med den er helt klart politisk, nemlig at give indvandrerne et sprog og dermed vende deres svaghed til styrke. Netop i England har raceuroligheder som følge af fremmedhad, dårlige sociale vilkår for indvandrerne, ghettoisering og usynliggørelse og fortielse af problemerne været hyppige. Det er fortielsen, Rushdie med sin bog gør noget ved, og han betegner selv sit projekt som et "forsøg på at erobre sproget". Et eksempel herpå er netop termen bastard, der almindeligvis har en entydig negativ betydning, men som Rushdie ved at bruge den offensivt får givet en positiv valør. Et andet eksempel kan tages fra beskrivelsen af den metamorfose, Saladin undergår efter ankomsten til England. Saladin, der ganske vist netop er kommet fra Indien, har levet det meste af sit liv i England, og han er som nævnt ganske anglofil. Sin hudfarve og herkomst kan han imidlertid ikke løbe fra, og arrestationen af ham er et godt eksempel på, dels fortielsen - fremmedpolitiet lytter overhovedet ikke til ham - og dels den måde Rushdie arbejder med sproget på: "Da de trak hans pyjamasbukser ned inde i den vinduesløse politibil, og han så de tæt krøllede mørke hår, der dækkede hans lår, brød Saladin Chamcha sammen for anden gang den aften; men denne gang begyndte han at fnise hysterisk, måske var han blevet smittet af sine vogteres fortsatte overstadighed. De tre mand fra fremmedpolitiet var særlig løsslupne, og det var en af dem - fyren med de udstående øjne, som viste sig at hedde Stein - der hev Saladin ud af sækken, alt imens han muntert råbte: "Så er det åbningstid, perker; lad os se, hvad du er lavet af!" De rødhvide striber blev trukket af den protesterende Chamcha; han lå på vognes gulv, mens to kraftige politifolk holdt i hver af hans arme, og med en femte politimands støvle solidt plantet på sit bryst, og hans protester druknede i det almindelige lystige spektakel. Hans horn blev ved med at støde ind i alt muligt, den indvendige hjulskærm, det tæppeløse gulv eller en politimands skinneben - ved de sidstnævnte lejligheder indkasserede han et par ordentlige lussinger fra den retfærdigt opbragte ordenshåndhæver - han var alt i alt i det elendigste humør, han kunne huske nogen sinde at have været i. Alligevel kunne han, når han så, hvad der lå under hans lånte pyjamas, ikke forhindre en vantro fnisen i at smutte over sine tænder.

Hans lår var blevet usædvanligt brede og kraftige, foruden behårede. Under knæene hørte behåretheden op, og benene snævrede ind og blev seje, benede, næsten kødløse lægge, der endte i et par skinnende helt spaltede klove, som man kan finde dem på enhver gedebuk. Saladin blev også noget bestyrtet over synet af sin egen fallos, som var stærkt forstørret og pinligt oprejst, et organ, som han havde den allerstørste vanskelighed ved at erkende som sit eget. "Hvad er nu den af?" spøgte Novak - den tidligere "Hvæser" - og kneb den muntert. "Kunne du godt tænke dig at komme i lag med en af os, hvad?" Hvorpå den "stønnende" repræsentant 
for fremmedpolitiet, Joe Bruno, klaskede ham på låret, stødte Novak i siden og råbte, "Ja, han er sgu' stangstiv." "Den forstod jeg godt," råbte Novak tilbage, idet hans næve tilfældigt dunkede Saladin i de nyligt forstørrede testikler. "Hej! Hej!" hylede Stein med tårer i øjnene. "Jeg har en, der er endnu bedre ... han har et horn i siden på os."

Hvorpå de tre, mens de den ene gang efter den anden gentog "Stangstiv ... horn i siden ...", faldt hinanden om halsen og hylede af begejstring. Chamcha ville gerne have sagt noget, men han var bange for at opdage, at hans stemme var blevet forvandlet til gede-brægen, og desuden var politimandens støvle begyndt at presse hårdere end nogen sinde mod hans bryst, så det var svært overhovedet at danne ordene. Det, der undrede Chamcha, var, at de andre behandlede en hændelse, som han opfattede som værende i allerhøjeste grad forvirrende og uden fortilfælde - altså, hans metamorfose til denne overnaturlige djævleunge - som om, det var det mest banale og dagligdags, man kunne forestille sig."7

Denne begivenhed eller metamorfose er imidlertid en banal hændelse i dagligdagens England - en hændelse, som overgår nye indvandrere hver dag. Det, der sker med Saladin, er simpelthen, at Rushdie i sin beskrivelse udstyrer ham med træk, som svarer til de helt almindelige billeder, mange mennesker har af de fremmede - en form for dæmonisering: de lugter, de er liderlige "og de tager vores piger", de er dyriske, og de kan ikke formulere sig; deres sprog er som "gedebrægen". Efter sin arrestation transporteres Saladin til et interneringscenter, en hospitals-lignende anstalt, og her møder han en broget og mangfoldig skare af besynderlige væsner. På spørgsmålet om, hvordan dette kan gå til, svarer en af skabningerne: "De beskriver os ... Det er det hele. De ejer beskrivelsens kraft, og vi bukker under for de billeder, de konstruerer". Det er med andre ord den diskurs om de fremmede, der producerer dem i den form, som de fremtræder for os. Sat på spidsen er der tale om en sprogkonflikt, der udspiller sig på det figurative niveau, altså gennem de mataforer, der dannes. Indvandrerkonflikten bliver dermed også til en konflikt om metaforer - $\mathrm{i}$ bund og grund en litterær konflikt - til et spørgsmål om at erobre metaforer og give dem ny betydning i en offensiv strategi, og det er præcis dette projekt Rushdie ser som romanens mulighed og fornemste opgave. Han udtrykker det selv med et Carlos Fuentes citat, når han siger: "Romanen er den privilegerede arena, hvor sprog i konflikt kan mødes".

Men er en kamp om metaforer egentlig ikke det samme som at udrydde fordomme gennem en almindelig oplysningsstrategi? Jo, både og. Spørgsmålet er på hvilket sprogligt niveau vi befinder os. F.eks er det ikke ualmindeligt, at personer, der på et niveau taler en bestemt sag i deres metaforanvendelse faktisk understøtter de fordomme, som de vil gøre op med. Der kan altså være en konflikt mellem et bevidst niveau, det intentionale niveau, og et retorisk niveau, der aldrig kan være helt bevidst, fordi det også indbefatter de regler, der overhovedet muliggør sprog. 
Sådanne regler kan imidlertid godt være styrende for, hvordan vi ser på forskellige sagsforhold, og en kamp på det retoriske niveau, metaforkampen, er derfor ikke blot en kamp om, hvad der siges, men i høj grad om, hvordan det siges. Med andre ord et møjsommeligt og systematisk sprogligt arbejde med sprog, og som det - i hvert fald ifølge Rushdie - er litteraturens fornemste opgave at påtage sig.

Metaforerne indgår som en del af diskursernes retoriske niveau, men Rushdies arbejde stopper ikke ved det. Det går videre til et arbejde med diskurserne som sådan, hvilket vi var inde på i forbindelse med bogens ironiske forhold til ideologi. Kort sagt er den destruktiv i sit arbejde med diskurser; den nedbryder herskende "fortællinger", hvilket Rushdie redegør for i sine essays ${ }^{8}$ med eksplicit reference til bl.a. dekonstruktion (J. Derrida) og postmodernisme (J.-F. Lyotard). Termen dekonstruktion er, hvis den ikke var så forbandet svær at definere, en præcis betegnelse for Rushdies projekt: skildes ordet ad, ses det at bestå både af ordet destruktion og af ordet konstruktion. Det destruktive element i romanen består simpelthen $i$ at pille glorien af de sprogformationer, vi kalder ideologi, og teknikken består i at litterarisere dem, dvs. i at tildele dem fiktionsværdi. En måde at gøre det på er at skrive en historie, der har umiskendelige lighedstræk med en, alle kender, men at indføre småændringer og at lade den udspille sig i en anden kontekst. F.eks. fortæller De sataniske vers ikke historien om islams tilblivelseshistorie, men den opfinder en anden, der umiskendeligt ligner og da er dén tanke jo nærliggende, at det åbenbarede også er fiktion. Ved at litterarisere sås der tvivl om sandhedsværdien; ikke gennem en direkte tematisering af den religiøse diskurs, men gennem en fiktiv imitation af den: ingen kan faktisk med rette beskylde Rushdie for i sin roman at have skrevet om islam: han har faktisk kun skrevet en fortælling, der ligner, men en fortælling, der helt klart understreger fiktionskarakteren i den både i drømmesekvenserne og i nedskrivningen af den. Hændelserne omkring nedskrivningen af Mahounds åbenbaringer i romanen er her illustrative: Mahound kan ikke selv skrive og må derfor have skrivere til at gøre arbejdet. En af dem, perseren Salman, ændrer imidlertid af æstetiske grunde på de diktater, han får, og den tekst, han skriver er altså ikke identisk med det, Mahound har modtaget fra ærkeenglen. Man kan her forestille sig en serie af gentagelser, der hver for sig indfører ændringer i teksten: Englens formidling til Mahound, Mahounds formidling til Salman, disciplens formidling til den nye discipel. Gentagelsen af teksten er aldrig identisk med teksten, fordi den kontekst, hvori gentagelsen finder sted, aldrig er det, og det er måske heri den største helligbrøde ligger: at gentage en religiøs tekst i en litterær kontekst. Det kan ikke undgå at ændre teksten afgørende; den bliver profaneret. Tilsvarende gælder det for alle tekster, der på den ene eller anden måde påberåber sig eller får tildelt en status af "lovtekst". Ved at gentage sådanne tekster i nye kontekster, altså ved at bringe dem på niveau med tekster af anden karakter, mister de deres status af "lovtekst". 
Gentagelsen af tekster i nye kontekster har været et fænomen, nyere tekstteori har været stærkt optaget af de sidste årtier, og begrebet intertekstualitet er i den forbindelse næsten blevet et modeord siden den fransk-bulgarske semiotiker Julia Kristeva definerede det i bogen La révolution du language poétique (1974). Hun skriver her: "To these we must add a third 'process' - the passage from one signsystem to another. To be sure, this process comes about through a combination of displacement and condensation, but this does not account for its total operation. It involves an altering of the thetic position - the destruction of the old position and the formation of a new one. The new signifying system may be produced with the same signifying materials; in language, for example, the passage may be made from narrative to text. Or it may be borrowed from different signifying materials: the transposition from a camival scene to a written text, for instance. In this connection we examined the formation of a specific signifying system - the novel - as the result of a redistribution of several different signsystems: carnival, courtly poetry, scholastic discourse. The term intertextuality denotes this transposition of one (or several) signsystem(s) into another."9 Destruktionen af et tegnsystem, en diskurs, finder altså sted, når den overføres og fortættes i et andet tegnsystem, men som Kristeva peger på sker der samtidig en dannelse af en ny diskurs, og det er heri det konstruktive element i termen dekonstruktion gemmer sig. Helt enkelt og firkantet kan Rushdies roman læses som en dekonstruktion af den eller de diskurser, der opererer med renhed og ubesmittethed som positive termer, hvilket betyder nedbrydelsen af dem og samtidig formationen af en diskurs, der opererer med hybridformer, bastarder, som positive størrelser. Pointen er, at denne proces kun kan ske ved at gå omvejen over en destruktion af de narrative og retoriske mønstre, der er strukturerende for måden, vi bruger sprog på og dermed ser (læser) verden på.

Teknikken er tydelig hos Rushdie, hvis bog kan ses som et stort intertekstuelt netværk. Som eksempel kan tages indledningen: ""For at fødes på ny," sang Gibriel Farishta, mens han styrtede ned fra himmelen, "så må man først dø. Ho Ji! Ho Ji! For at lande på den skødbløde jord, så må man først flyve. Tat-taa! Takathun! Hvordan kan man smile på ny, uden først at have grædt? Hvordan kan man vinde den elskedes hjerte uden et eneste suk, min herre? Baba, hvis du vil fødes på ny ... " Lige før daggry en vintermorgen, nytårsdag eller deromkring, faldt to fuldvoksne, levende mænd fra stor højde, niogtyve tusinde og to fod, mod den Engelske Kanal, uden hverken faldskærme eller vinger til hjælp, fra en klar himmel.

"I tell you, you must die, I tell you, I tell you," og således og på denne måde fortsatte han under alabatermånen, indtil et højt råb skar gennem natten, "Til helvede med dine sange," ordene hang som krystaller i den frosne hvide nat, "i filmene mimede du bare til playback, så skån mig nu for det infernalske spektakel."

Gibreel, den tonedøve solist, voltigerede i måneskinnet, mens han sang sin improviserede gazal, han svømmede i luft, butterfly, brystsvømning, krummede sig 
sammen til en kugle, strakte arme og ben ud mod næsten-daggryets næstenuendelighed, indtog heraldiske positurer, opspringende, liggende, og satte lethed ind mod tyngde." ${ }^{10}$ Der er i dette citat klare referencer til Skabelsesberetningen, Lucifer, teorien om The Big Bang vævet sammen med citater fra f.eks. den amerikanske rockgruppe The Doors og den tyske filosof Friedrich Nietzsche og dertil kommer klare dionysiske træk. Endvidere refereres der i konteksten til en faktisk begivenhed, nemlig bombesprængningen af et Air India Boeing 747 over det sydvestlige Irland i 1985 - en handling, der formodes at være begået af sikhiske terrorister. Denne blanding af referencerammer tjener udover det allerede nævnte også til understrege fiktionskarakteren: teksten handler om noget fra den virkelige verden, men på en eksperimenterende måde. Endelig tjener indledningen naturligvis til at anslå bogens gennemgående tema: at fødes på ny, hvilket er det, der sker, når man bevæger sig fra en kultur til en anden. Der sker på den ene side et tab uden at dette tab umiddelbart finder en erstatning med det resultat, at den faldne svæver i et tomrum. Med de klare religiøse referencer bliver det kulturelle tomrum sat i analogi til et religiøst tomrum mellem hellighed og ateisme; dekonstruktionen af den kulturelle diskurs om renhed følges af en parallel dekonstruktion af diskursen om religiøs renhed, og der bliver sat omend ikke identitet, så dog en tydelig sammenhæng mellem kulturel chauvenisme og religiøs fanatisme. Dermed vælger bogen ikke mellem to kulturer, mellem islam og vesten, men insisterer på bastardisering af begge. Sammenhængen mellem litteratur og politik er overvældende i denne overordentligt litterære roman: Bastardiseringen vil ingen ende tage. Er der et angreb i Rushdies roman retter det sig således hverken éntydigt mod islam, mod vesten, mod kristendom eller mod Thatcherisme, men mod enhver form for absolutistisk diskurs. Lige så meget mod selvtilstrækkelige engelske anti-muslimer som mod islamiske fanatikere med Khomeini i spidsen. Det er faktisk ironisk, at det er de indvandrere i Bradford, hvis sag Rushdie med sin roman faktisk også vil tale, der står for bogafbrændingerne og at det er den Thatcher, hvis England romanen også sviner til, der står som den største forsvarer af manden og dermed som den inkarnerede ytringsfrihed. Har dette virkelig alt sammen noget med religion at gøre? Måske nok, men det har i lige så høj grad noget at gøre med fænomenet litteratur eller rettere skriftlighed. Som nævnt er bogens hovetema en konflikt mellem to identitetstyper: migranten og nationalisten og som nævnt i forlængelse af Hegel er et grundtræk i den europæiske civilisation skriftlighed. Det nærliggende spørgsmål er da, om der er en sammenhæng mellem skriftlighed og nationalisme, mellem romanen og nationalstaten? Er det sådan, at den konflikt, der udspillede sig i forlængelse af De sataniske vers, i grunden er en konflikt mellem to kulturer, den ene skriftlig og litterær, den anden mundtlig og alitterær - en konflikt mellem det talte og det skrevne? 


\section{Forskellen mellem øret og øjet som kulturforskel}

Was vernüftig ist, das ist wirklich; und was wirklich ist, das ist vernüftig.

Hegel

Konflikten mellem det talte og det skrevne er gammel i europæisk civilisation og kan i hvert fald spores tilbage til diskussionen i Platons dialog Faidros: Det er her, at myten om Theuth, opfinderen af bogstavskriften, fortælles, og som bekendt bliver denne opfindelse ikke vel modtaget. Thamus, der skal vurdere opfindelsen, siger: "Vidunderlige snilde Theuth, en har evner til at skabe opfindelser, en anden til at dømme om, hvorvidt disse vil være til skade eller gavn for dem, der skal bruge dem. $\mathrm{Nu}$ har du som fader til bogstavskriften af lutter velvilje tiltroet den den modsatte virkning af den, den virkelig har: For det er glemsomhed, der vil blive den sjælelige følge af de mennesker, der lærer at skrive; hukommelse vil de ikke bekymre sig om, fordi de i tillid til bogstavskriften lader deres erindring vække udefra af uvedkommende bogstavformer, ikke indefra ved deres egen selvvirksomhed. Det er altså ikke et middel til at fremme erindring, men til at fremkalde ydre påmindelse, du har opfundet. Og hvad angår visdom, da vil du kun kunne skaffe dine elever et skin af viden, ingen sand erkendelse. De får, takket være dig, hørt en masse ting, men lærer ikke noget; de vil få skin af at have en masse kundskaber, skønt de på få undtagelser nær er vidende og ubehagelige at omgås, i besiddelse af skinviden, uden virkelig visdom."11

Sammenholder vi denne vurdering, citeret af Sokrates og nedskrevet af Platon, med Hegels vurdering, "at dette at læse og skrive en alfabetisk skrift må betragtes som et uendeligt dannelsesmiddel", kan forskellen vel knap være større. Det er nærliggende at se denne forskel som udtryk for to helt forskellige måder at være i verden på: en måde, der baserer sig på religion eller religiøse værdier, hvor målet er det gode samfund, og en måde, der baserer sig på erkendelse, hvor målet er det fornuftige samfund. Det fornuftige samfund baserer sig på skrift, mens det gode samfund baserer sig på talen og ser skriften som en undergravende aktivitet - meget konsekvent har det gode samfund derfor heller ikke plads til forfattere. Helt enkelt er skriften undergravende i forhold til det moralsk gode først og fremmest fordi den producerer en masse viden, der i virkeligheden ikke er viden baseret på indsigt (visdom), men overfladisk skinviden; en viden, der ikke er dyb nok, en dekadent viden. En sådan viden, der kun baserer sig på overfladiske, tomme tegn (Platon), er imidlertid en viden, som alle i princippet kan tilegne sig, lære, formidle videre og endog sælge for penge. Viden på skrift kan udbredes, sælges på et marked, faldbydes til alle og enhver, instrumentaliseres, og det var faktisk, hvad antikkens sofister gjorde, og hvad Sokrates ikke kunne have. Og hvordan ser man i grunden 
forskel på en sofist og én, hvis viden er baseret på dyb indsigt? Ja, det er ikke til at vide, hvis man ikke lige ved det, og det er lige præcis her humlen ligger begravet, for dermed står den vises autoritet i fare. Følgen er, at et hierarkisk opdelt samfund, hvor magtstrukturerne baserer sig på - eller i hvert fald legitimeres gennem - indsigt i de moralske værdier, kun vanskeligt kan opretholdes, såfremt skriften holder sit indtog.

Dette er pointen i Sokrates' kritik af skriften, og for ham eksisterede det skrift heller ikke, som rummede nøglen til den sande indsigt. Hegel, der i det citerede afsnit, berømmer den alfabetiske skrift som det grundlag, der muliggør moderniteten, har mange andre steder i sit værk udfald mod skriften, der ikke står tilbage for Sokrates'. Den franske filosof Jacques Derrida har i en række detaljerede studier vist, at konflikten mellem det talte og det skrevne på et filosofisk-ideologisk niveau er et grundtræk i den vestlige filosofis historie; at filosofien konsekvent og kun med enkelte undtagelser fra Platon til det 20. århundrede privilegerer talen som stedet for sand indsigt og lægger afstand til skriften, der kun producerer overfladisk skinviden. Dette på trods af, at udviklingen af den vestlige civilisation kun meget vanskeligt kan beskrives uden at tildele skriften samt dens almengørelse og udbredelse gennem trykkekunsten og varemarkedet en særdeles afgørende rolle i denne proces. Skriftskritikken er en nostalgisk og moralsk kritik, der er helt parallel med de nostalgisk-moralske kritikker, vi kender til, af f.eks. den moderne teknologi og af massemedierne. Kritikken er nostalgisk, fordi den henter sine begreber: harmoni, sammenhæng, fællesskab, nærhed, naturlighed fra en førmoderne verden, og moralsk, fordi den ser skriften, teknologien og medierne som amoralske fænomener, der udvikler sig hinsides godt og ondt: de er med andre ord grundlæggende for den sækularisering, der kendetegner den vestlige verden. Den moderne nihilisme, altså det, at der ikke er nogen Mening bag ved det moderne samfunds institutioner, organisationsformer og udvikling, kan ses som et direkte resultat heraf. Det at læse og skrive er ikke blot en ufravigelig betingelse for at kunne gebærde sig i den moderne vestlige civilisation, men er samtidig det, som mest grundliggende karakteriserer denne civilisation til forskel fra andre kulturer, og selv den mest nostalgiske moralist vil vel næppe gå så langt i sin kritik, at denne vil munde ud i et forslag om afskaffelse af læsning og skrivning som element(et) i opdragelsen af vore børm. Og så lang tid indøvelsen i den alfabetiske verden er det, der fylder mest i børnenes indøvelse i civilisation, så lang tid vil denne civilisation - til forskel fra andre kulturer - være en meningsløs skriftkultur.

To spørgsmål presser sig imidlertid på. For det første: hvorfor har den vestlige civilisation som den eneste udviklet sig til at være en skriftbaseret kultur, og for det andet hvad betyder det egentlig? Med hensyn til det første spørgsmål skal et svar kun antydes her. Allerede tidligt i den europæiske middelalder splittes magten i to centre, der i Augustins formulering tager sigte på gudsstaten, respektive, verdensstaten og 
som fører til adskillelsen mellem kirke og stat. Denne proces forstærkes op gennem middelalderen, og den kan sammenfattes på følgende måde: "Stat og kirke er myndighederne inden for de to livsområder. Det vil sige, at de rent principielt er uafhængige af hinanden. Staten skal f.eks. opbygges efter fornuftens principper for at give hele den dennesidige del af tilværelsen sin struktur og orden. Men da alt i dette lavere lag af livet foruden at have sit eget væsen og sin egen mening desuden stiler mod det højere og først når sin fuldendelse, når det højere føjes til, så er alligevel i sidste instans også statens mål lagt uden for formuftens eget område. Det betyder, at staten rent faktisk ikke kan indrette sig på ret vis uden at støtte sig til og hente hjælp fra kirken. Det er igen ikke et overgreb fra kirkens side; tværtimod: kirken skal sætte staten i stand til omsider at blive sig selv". ${ }^{12}$

At stat og kirke adskilles betyder, at politikken ikke er bundet til religiøse værdier og på længere sigt, at såvel det politiske som det religiøse kan udvikle sig til selvstændige sfærer i samfundet, der tager vare på forskellige livsområder og betjener sig af hvert sit sprog: det politiske og det religiøse udfolder sig i forskellige diskurser. Det betyder også en splittelse i magten mellem den verdslige magtudøvelse og kontrollen af de åndelige værdier, og det er klart, at kan sindelagskontrollen ikke gennemføres ved betjening af statens voldsmonopol, da står denne kontrol svagt over for konkurrerende og kætterske alternativer. Splittelsen i magten førte også til en splittelse inden for kirken mellem forskellige retninger "og behovet for at kunne tage del har givetvis tilskyndet til opfindelsen af bogtrykkerkunsten, jævnfør de mange, der på samme tid konkurrerede med Gutenberg om at komme først med et konkurrencedygtigt informationsmedium. Der kan heller ikke være tvivl om, at bogtrykkerkunsten, da den først forelå, fremmede debatten og uddybede modsætningerne". ${ }^{13}$ Det er med andre ord splittelserne i det europæiske, der både muligg ør og tilskynder udbredelsen af skriften. Den kristne religions rolle er endvidere i forhold til andre religioner, f.eks. islams, helt speciel, idet den historisk set (måske også dogmatisk) tilskynder til en sækulariseringsproces: Paradoksalt nok er kristendom og sækularisering blevet to sider af samme sag individets og modernitetens sag. Karakteristisk er det i denne sammenhæng, at såvel filosoffen Hegel som sociologen Max Weber gør protestantismen til en af de afgørende faktorer i dannelsen af den moderne vestlige nationalstat. Under alle omstændigheder tager den kristne kirke hurtigt bogtrykkerkunsten i sin tjeneste, og da den først er organiseret og etableret er den trods flere ihærdige forsøg umulig at stoppe; bogtrykkerkunsten bliver den første egentlige industrialiserede produktion og tryksagen den første egentlige massefremstillede vare - en vare, der på den ene side er alt for let at masseproducere og på den anden side alt for let at sælge for penge til at dens udbredelse kan stoppes ved bål og dekreter.

Fra og med renaissancen udvikler den vestlige civilisation sig således til en skriftkultur. Det bemærkelsesværdige er, at det er der ikke andre kulturer, som gør, 
ej heller den arabiske. Forklaringen på dette er hverken teknologisk eller intellektuel, men politisk: Hvor magten i Europa som nævnt var splittet, var religion og politik i Det osmanniske Rige som overalt $i$ islam en enhed. Den politiske organisation af staten og religionen er udsprunget fra samme kilde og er i sit udgangspunkt en enhed, hvor den religiøse tolkning af verden samtidig udgør fundamentet for den politiske organisering. Der var (og er) mao. ikke et konkurrerende modsætningsforhold mellem det politiske og det religiøse som mellem kristendom og kejserdømme. Den politiske og den religiøse diskurs er i princippet sammenfaldende og betjener sig af det samme sprog og den samme retorik.

At politik og religion ikke er adskilt betyder, at politiske synspunkter, hvis de skal virke overbevisende, bygger på en sprogbrug og en tankegang, der klart henviser til de hellige skrifter. Som et aktuelt eksempel kan nævnes Saddam Hussains taler i forbindelse med konflikten om Kuwait, hvor han hele tiden anvendte citater og vendinger fra Koranen, når han skulle gøre sine synspunkter gældende. Det politiske og det religiøse er sammenvævede $\mathrm{i}$ en helt anden forstand, end vi har tradition for i vesten. Det gør, at vi har en tendens til at overvurdere det religiøse element i disse samfund og tilsvarende undervurdere det politiske. Konflikter, som formuleres i et sprog, der klart henviser til religiøse begreber, har også en sociologisk og økonomisk baggrund og er derfor som regel ikke blot religiøst funderede, men må ses som udtryk for reelle politiske interessemodsætninger.

Et andet eksempel på sammenvævningen af politik og religion i den islamiske verden er den konflikt, der gav anledning til en spittelse i islam mellem de to hovedretninger shia- og sunniislam. Kort sagt var problemet en konflikt om, hvem der skulle være overhoved i den islamiske verden. Nærmere bestemt en konflikt om, hvem der var den retmæssige arvtager (kaldet kalif) til Muhammad efter hans død i 632 e.v.t. I første omgang valgte man en fra Muhammads egen Kuraish-stamme, der samtidig havde vist sin duelighed i kampen for islams indførelse. Hermed forbigik man imidlertid Muhammads fætter og svigersøn Ali og dermed Muhammads nærmeste slægning, der ifølge arabisk skik havde førsteret til kalifværdigheden. Dette gav anledning til en regulær magtkamp mellem dem, der insisterede på en egentlig arvefølge som betingelse for kalifatet, shiiterne, og dem, der lagde egnethed og ikke blodsbånd til grund for valget, sunnierne. Denne magtkamp handlede altså ikke blot om religiøse uoverensstemmelser, men også om magt og indflydelse. Shiiterne opnåede hurtigt en stor udbredelse, og dette kan delvist også begrundes i politiske og sociologiske forhold: Islams ekspansion i århundredet efter Muhammads død omfattede nemlig områder, der indbefattede ikke-arabiske befolkninger, f.eks. persiske, eller arabiske områder, der var befolket med folk af anden herkomst. Skønt disse omvendte sig til islam og som sådan efter muslimsk skik og brug burde nyde samme rettigheder som egentlige arabiske muslimer, så var dette ikke altid tilfældet. Dette var selvsagt en kilde til politisk uro, og det var bl.a. i 
sådanne grupper, at shiismens rødder kan spores. Skønt forskellene mellem shia og sunni kan lokaliseres i forskellige måder at tolke islam på, f.eks. forskellige vægtninger af imambegrebet, så ville det være forkert at identificere forskellen som alene en religiøs forskel. Meget tyder faktisk på det modsatte, at politiske interessemodsætninger udspiller sig og formulerer sig i et religiøst sprog, og at den dogmatiske forskel i sit udgangspunkt har politiske og sociologiske årsager. Pointen er i al sin enkelhed, at det politiske ikke udspiller sig i en selvstændig diskurs, men at den politiske og den religiøse magt var og er integreret. Dette betød, at bogtrykkunsten ikke udviklede sig udover i marginalgrupper indtil i hvert fald 1800tallet. For det første var der ikke den samme tilskyndelse til det, som splittelsen i Europa udgjorde, og for det andet betød integrationen af den udøvende magt og sindelagskontrollen en effektiv kontrol- og censurinstans. Alt dette betyder naturligvis ikke, at den islamiske verden kan beskrives som en ren mundtlig kultur. Men der er tale om en kultur, der den dag i dag stadig er båret af strukturer, som former mundtlige kulturformer. Dermed kan vi vende os til det næste spørgsmål, nemlig hvad det betyder, at en kultur er mundtlig, respektive skriftlig?

\section{Talens magt og skriftens revolte}

I sommeren 1990 var jeg stipendiat ved L'Institut Bourguiba des Langues Vivantes i Tunis, hvor jeg deltog i et intensivt kursus i arabisk sprog. Umiddelbart virker byen Tunis som en europæisk (fransk) by: påklædningen er afslappet, omend ikke så udfordrende som vi er vant til, man klarer sig ligeså godt med fransk som med arabisk, øller kan drikkes i dertil indrettede ølstuer og supermarkederne sælger vin om eftermiddagen. Opholder man sig lidt længere, opdager man selvfølgelig de muslimske træk: VM-finalen i fodbold afbrydes af aftenbønnen, der er bestemte mønstre for, hvor og hvornår man møder pigerne, og ind i mellem render man også ind i det fænomen, vi europæere kalder omvendt racisme. Alligevel er oplevelsen af at befinde sig i et muslimsk land begrænset. Dette gælder også på sprogskolen, hvor vi var omkring 600 udenlandske studerende, fortrinsvist spanske og italienske og fortrinsvist afslappet påklædte piger. Der var ingen kønsadskillelse på holdene og vores lærer f.eks. var en kvinde.

Hurtigt efter at undervisningen er gået igang, erfarer man dog, at pædogogikken er en ganske anden end den erfarings- og elevorienterede pædagogik, vi er bekendt med: Pædagogikken var klart autoritær og lærerstyret; eleverne skulle kun gøre, hvad de fik besked på, og der var med andre ord. et klart hierarkisk forhold mellem lærer og elev. Hurtigt udviklede vi en adfærd, hvor vi forsøgte at gemme os for læreren for at undgå at blive hørt. Vi opførte os som små bange skolebørn på trods af, at de fleste af os var voksne uddannede mennesker. Eksempelvis kom en 45-årig 
fransk flyingeniør en dag et par timer for sent til undervisningen pga. trafikproblemer. Manden fik af læreren besked på straks at henvende sig på rektors kontor forsynet med et brev fra læreren - det mest overraskende var, at han gjorde det! Dette på trods af, at manden gik på kurset frivilligt af interesse for det arabiske og ovenikøbet havde betalt tusinde af kroner for at gå der.

Selve undervisningen foregik som kor-repetitioner efter læreren: hun sagde et eller andet, der i starten var det rene kaudervælsk for os, og så gentog vi på samme måde, som man i barndommen lærte alfabetet. Herefter pegede hun elever ud, der skulle gentage de samme lyde enkeltvist, og gud nåde og trøste den, der ikke promte kunne rable ordene af sig; vedkommende kunne være sikker på at blive skammet ud og hånet i de andres nærvær. Det overraskende var, at der ikke gik lang tid, før man helt ændrede sin adfærd og attituder i undervisningssituationen som resultat af en pædagogik, der ikke var motivationsorienteret, men alene betjente sig af stokkemetoden.

Et andet faktum vi undrede os meget over var forbudet mod enhver form for notatteknik og trykte hjælpemidler. Det skyldtes faktisk ikke, at der ikke forelå en lærebog, for det gjorde der, og vi fik den også udleveret tre uger inde i kurset. Endda en pædogogisk veltilrettelagt bog med gode øvelser, tekster, illustrationer og opgaver. Problemet var bare, at vi ikke måtte bruge den. Derimod skulle vi lære historierne i bogen udenad efter lærerens diktat. Tilsvarende var enhver brug af ordbøger og grammatikker forbudt, og fandt man på at lave notater til hjælp ved udenadslæren, blev de straks konfiskeret. Hvorfor denne restriktive holdning over for det skrevne medium? I første omgang tilskrev vi det det forhold, at skolen lagde vægt på det levende sprog (langues vivantes) og at det var et pædagogisk princip, at sproget blev lært gennem øret og ikke gennem øjet. Men dette forklarer langt fra den meget autoritære undervisningsform og heller ikke den udstrakte anvendelse af gentagelser i kor af lærerens diktater.

I sin meget læseværdige bog Orality and Literacy. The Technologizing of the Word (London 1982/90) redegør Walter J. Ong for forskningen i de strukturelle forskelle, der gør sig gældende mellem mundtligt- og skriftligtbaserede kulturer, og på en klar måde sammenfatter han resultaterne. Bemærkelsesværdigt i forbindelse med Bourguibaskolens pædagogik redegør han for, at pædagogik, der ikke baserer sig på skrevne tekster, altså en mundtlig kulturs pædagogik, netop betjener sig af to eller fleres samtidige gentagelser af hørte sætninger: der eksisterer ingen tekst og følgelig heller intet tekstbillede, hvorfor sproget er ren lyd med den konsekvens, at al viden kun kan indlæres gennem repitationer via hørelsen. Den for os fremmede pædagogik i Tunis skyldes således i mindre grad et avanceret pædagogisk princip om "det levende ord", men langt snarere, at der er tale om den type pædagogik, som udfoldes i mundtlige kultursammenhænge. Samtidig kan vi bemærke en kulturel konflikt: lærebøgerne er der jo, men det er karakteristisk, at kulturer, der befinder 
sig i en overgang fra oralitet til litteraritet, betragter de trykte medier med en udpræget grad af skepsis og mistænksomhed. Det gælder i pædagogikken, og det gælder i pressen, i litteraturen og til en vis grad også i lovgivning og retspraksis. Det tunesiske eksempel er ikke enestående. Tværtimod er Tunesien et af de lande i den region, vi kalder Mellemøsten, der er gået længst i retning af en form for vesternalisering. I andre dele af regionen er orale præg langt mere udtalte, og tager vi regionen under ét, kan der henvises til en analfabetisme på ikke under 50\%, at der ingen steder findes en fri presse eller trykkefrihed, at pædagogikken fra de rurale koranskoler til engelskundervisningen i de relativt moderne skoler i Bagdad ligner Bourguibaskolens, at der i lande som Saudi Arabien og Iran stort set ikke findes andet typografisk lovgrundlag end Koranen - og her kan man jo fundere lidt over, hvad det har af konsekvenser for f.eks. juraen i trafikspørgsmål, når retsgrundlaget skriver sig tilbage til det 8. århundrede. Hermed er der naturligvis ikke dokumenteret, at Mellemøsten er en oral kultur - dette får i denne sammenhæng lov til at stå som en påstand. Det skal også - som eksemplet fra Tunis viser - bemærkes, at der ikke er tale om rene orale kulturer, men kulturer, der befinder sig i et grænseområde mellem oralitet og litteraritet. De følgende bestemmelser af orale kulturer i kontrast til skriftkulturen, der fortrinsvist er hentet fra Ongs bog, er udviklet på baggrund af kulturer, hvor tekstlighed er fuldstændigt fraværende, og når de overføres på Mellemøsten skal de derfor tages med forbehold. Omvendt tegnes forskellene klarere og skarpere op.

\section{Oralitet}

En grundlæggende forskel er måden, hvorpå sprog fremstilles. I skriftkulturen kan man tale om, at sproget er visuelt; ordene og tingene hænger ikke sammen, er ikke substantielt bundne til hinanden. Ordene er snarere etiketter, der mere eller mindre vilkårligt kan klæbes på ting. Lad os tage et eksempel. I Kierkegaards Enten - Eller findes følgende aforisme: "Det, philosopherne tale om Virkeligheden, er ofte ligesaa skuffende som naar man hos en Marschendiser læser et Skildt: Her rulles! Vilde man komme med sit tøi for at faa det rullet, var man narret, thi Skildtet er blot tilsalgs". Denne aforisme er et godt billede på, hvordan sproget i en skriftkultur fungerer løsrevet fra situationen og på, hvordan ordene kan optræde som synlige etiketter løsrevet fra enhver konkret kontekst. Ordene taler til os gennem øjet og det, Kierkegaards æstetiker er skuffet over, er, at der er en distance mellem "Virkeligheden" og talen: Det betyder, at der ikke er nogen nødvendig sammenhæng mellem sprog og handling; en sætning behøver ikke nødvendigvis give anledning til en handling. Vi kan arbejde i og med sprog løsrevet fra de situationer og kontekster, det omhandler. I modsætning hertil er sprog i orale kulturer situationsbundet og 
handlingsorienteret. At sprog er visuelt, en selvstændig størrelse på afstand af en konkret livsverden, muliggør kategorisering, analytik og abstrakt formel tænkning, hvilket ikke er muligt, når sproget er situationsbundet. Ong refererer her et eksempel fra Aleksander Lurias feltstudier blandt analfabeter i Kirgisien: "Subjects were presented with drawings of four objects, three belonging to one category and the fourth to another, and were asked to group together those that were similar or could be placed in one group or designated by one word. One series consisted of drawings of the objects hammer, saw, log, hatchet. Illiterate subjects consistently thought of the group not in categorial terms (three tools, the log not a tool) but in terms of practical situations - 'situational thinking' - without adverting at all to the classification 'tool' as applying to all but the log. If you are a workman with tools and see a log, you think of applying the tool to it, not of keeping the tool away from what it was made for - in some weird intellectual game. A 25-year-old illiterate peasant: 'They're all alike. The saw will saw the log and the hatchet will chop it onto small pieces. If one of these has to go, I'd throw out the hatchet. It doesn't do as good a job as a saw'. Told that the hammer, saw, and hatchet are all tools, he discounts the categorial class and persist in situational thinking: ' Yes, but even if we have tools, we still need wood - otherwise we can't build anything. Asked why another person had rejected one item in another series of four, that he felt all belonged together, he replied, 'Probably that kind of thinking runs in his blood"". ${ }^{14}$

På tilsvarende måde opregner Ong en række andre karakteristika for tænkning og udtryk i orale kulturer: Den sproglige stil er additativ fremfor underordnet (hypotaktisk) med udstrakt anvendelse af 'og'; ophobende fremfor analytisk, f.eks. den tapre soldat fremfor soldaten, den smukke prinsesse fremfor prinsessen osv.; ordrig fremfor stringent, hvilket hænger sammen med, at der i talen ikke som i teksten kan gås tilbage, og det er derfor nødvendigt med mange gentagelser af det netop sagte for at opretholde kontinuitet; traditionsbevarende fremfor udviklende; sproghandlingen er som nævnt nært knyttet til livsverdenen og situationen og dermed konkret fremfor abstakt. Endvidere fremhæver han oraliteten som agonistisk: "Many, if not all, oral or residually oral cultures strike literates as extraordinarily agonistic in their verbal performance and indeed in their lifestyle. Writing fosters abstractions that disengage knowledge from the arena where human beings struggle with one another. It seperates the knower from the known. By keeping knowledge within a context of struggle. Proverbs and riddles are not used simply to store knowledge but to engage others in verbal and intellectual combat: utterance of one proverb or riddle challenges heares to top it with a more opposite or contradictory one". ${ }^{15}$ Af en række andre træk skal her til sidst blot fremhæves, at talen er participerende i modsætninmg til objektiv distanceret.

Det er klart, at sådanne træk giver sig markante udslag som forskelle i samfundsmæssig organisation: Hvordan finder en social organisation egentlig sted, 
når der ikke findes tekster? Hvordan registreres folk og hvordan sikrer man f.eks. ordnede arveforhold? Hvor alle nødvendige informationer til social regulering i skriftkulturen er tilgængelig i kartotekerne og arkiverne må der findes andre former i mundtlige kulturer, og i den islamiske verden finder organiseringen sted gennem biologiske relationer: geografi (bosted), køn, alder og slægt/stammerelationer. Da jeg var i Yemen sidste efterår blev vi, såsnart vi kom lidt væk fra de store byer, stoppet af grænseposter, der kontrollerede trafikken mellem stammeterritorierne. Dette på trods af, at disse traditionelle stammegrænser med samlingen af Yemen og den nye forfatning blev afskaffet 1990/91. Med andre ord har den moderne nationalstatslige kontrol endnu ikke slået igennem i landet, hvor infrastrukturen stadig kontrolleres og reguleres på baggrund af stammeterritorierne, hvis grænser er naturligt fastlagte på grund af det bjergrige terræn. Den berygtede islamiske kønsadskillelse kan alt andet lige betragtes som en socialteknisk foranstaltning, der sikrer, at man har kontrol over børnenes tilhørsforhold: "uægte børn" skaber simpelthen uorden i arveforholdene med økonomisk og slægtskabsmæssig kaos tilfølge og dermed social uorden og instabilitet. Køn og slægt/stammeforhold regulerer økonomi og ressourcer og sikrer en gennemskuelig social orden, der kan opretholdes uden brug af skrift. I en oral kultur finder der selvsagt ikke nogen nedskrivning af historiske begivenheder sted, og den historiske bevidsthed begrænser sig derfor til den viden, der er gemt i de fortællinger, som cirkulerer, og til de personer, der kan huske. Alderen får her betydning, for jo ældre, man er, desto længere tilbage kan man huske, og desto større viden er man i besiddelse af. At den historiske bevidsthed er lokaliseret i erfaringstætte fortællinger, peger endvidere på et andet fænomen, nemlig en tidsbevidsthed, hvor tid også er bundet til biologiske relationer: Tidsmåling finder sted gennem konkrete forhold som afstande, naturrytmer og kropsfunktioner og ikke gennem abstrakte tidsnormer bestemt gennem uret.

Endelig skal et sidste forhold bemærkes, der ikke alene kan tilskrives fraværet af typografisk kultur, men som alligevel er nært sammenhængende hermed, nemlig en særlig form for forvaltningsform og statsopfattelse. I en oral sammenhæng er de mellem-menneskelige relationer hierarkisk strukturerede, og forholdet mellem stat og befolkning, dvs. hersker og undersåt, er et klart over- underordningsforhold, hvor magtens formidling er direkte og ikke som i den vestlige skriftkultur formidlet gennem en offentlighed. Tilstedeværelse af offentlighedsformer forstået som repræsentationsbestemt samfundsmæssig formidling mellem stat og borger vil altid også være en litterær offentlighedsform, der kun kan fungere og komme i stand, forsåvidt befolkningen er skolet i læsning og skrivning. Naturligvis findes der offentlighedsformer i de islamiske lande, men da som lederens tale til folket eller som imamernes tale i moskeerne. Et andet eksempel skal nævnes, nemlig den juridiske praksis: $i$ et land som f.eks. Saudi Arabien har man ingen anden 
konstitution end Koranen, og lovgrundlaget udgøres primært af de forskrifter, der udledes af Den hellige Skrift samt af sædvane og skik. I Iran har man en grundlov, men man forsøger at basere lovgivningen på islamisk lov, sharia, hvilket i praksis vil sige islamiske teologers tolkning heraf. Imidlertid giver det - i hvert fald med vestlige øjne - nogle problemer, når det f.eks. drejer sig om trafiklove eller toldbestemmelser, for meget af den juridiske praksis kommer til at basere sig på skøn - moralske skøn. I Saudi Arabien har trafiklove karakter af kongelige dekreter, der i princippet kan ændre sig fra dag til dag. Ingen kan heller med sikkerhed vide, hvad man præcist kan tage med ind i landet; selvfølgelig er der ting, man helt sikkert ikke kan tage med som f.eks. billeder af letpåklædte damer, oversættelser af Koranen, jødisk litteratur, bibler osv., men til syvende og sidst beror det på sædvane, stemningen i landet samt funktionærens lune. Der er med andre ord et meget mere direkte magtforhold mellem funktionæren og dommeren på den ene side og borgeren/undersåtten på den anden side, og for en vesterlænding forekommer det yderst urimeligt, at der ikke foreligger skriftlige, ajourførte dokumenter, som fastlægger en praksis.

Fraværet af skriftbaserede offentlighedsformer, der formidler interessekonflikter, betyder, at det politiske er en statslig opgave, som egentlig ikke vedkommer befolkningen, der på sin side heller ikke er engageret i en politisk offentlighed. Det er ikke abstrakte størrelser som samfund og stat, der fylder den almindelige muslims verden, men hverdagen, arbejdet, familien og slægtens videreførelse. Selvfølgelig er der her stor forskel på den muslim, der bor i storbyen, og den, der fortsat ernærer sig som bonde på landet, men procenten for valgdeltagelse ved parlamentsvalget $\mathrm{i}$ Ægypten i 1987 er alligevel sigende: den var kun omkring 25\%. At en udpræget grad af oralitet vanskeliggør gennemførelsen af et så abstrakt fænomen som demokrati, skal ikke tolkes derhen, at den "muslimske folkesjæl" er en hindring for demokrati og menneskerettigheder, eller at de muslimske befolkninger ikke er "modne" til demokrati. Der er blot peget på, at der er en nær sammenhæng mellem demokrati og litteraritet, og dette kan vel også give et fingerpeg om, hvorfor stort set alle styrerne i Mellemøsten er så meget på vagt over for en skriftens udbredelse, som de faktisk er. En højere grad af litterarisering af de mellemøstlige befolkninger vil alt andet lige virke undergravende på de eksisterende hel- og halvdiktatoriske styrer.

\section{Skriftlighed}

Skriftens civilisatoriske tendens kan lokaliseres i en lang række forhold, hvoraf jeg kun vil fremhæve to, nemlig etableringen af en abstrakt tidsbevidsthed og skriftens aktive nihilisme. Tid som et lineært, indholdstomt og kvalitetsløst fænomen er af relativ ny dato og sammenfaldende med etableringen af en kapitalistisk pro- 
duktionsmåde. Etableringen af den abstakte tidsbevidsthed er studeret af især marxistisk orienterede socialisationsteoretikere, hvor den bindes sammen med overgangen til industriel produktion, der forudsætter en konstant kapitalisering af maskinerne. I en sådan proces er det maskinerne, der bestemmer rytmerne i arbejdet, og hvornår, der kan holdes pause - ikke maven eller solens stilling på himlen. Teoretikere som Michael Vester og Alfred Krovoza har redegjort for, hvordan oprøret mod maskinerne i den tidlige engelske kapitalisme netop rettede sig mod destruktion af fabrikssirener og ure: Den abstrakte og mekaniske tid blev oplevet som et voldeligt overgreb mod en livsverden, der var orienteret mod konkrete, biologisk bestemte situationer. I dag finder det, der så malende er blevet kaldt "internaliseringen af det abstrakte arbejdes tidsnormer", sted før arbejdsprocessen, nærmere bestemt i den socialisering, børnene gennemgår, når de skal lære at læse og skrive. Det at lære at læse og skrive er en lang og tidskrævende proces, som stiller store krav til disciplin. Skolen er ikke blot en lærdomsanstalt, men stedet, hvor børnene lærer at passe tiden; komme til tiden, holde fri til tiden, spise til tiden, aflevere opgaver til tiden, løse opgaver inden for mere eller mindre vilkårligt valgte tidsrum, f.eks. 5 timer i et eksamenslokale, og denne disciplinerings-, socialiserings- eller dannelsesproces tager mindst 9 år af hver eneste danskers liv. Indøvelse i skrift og indøvelse i abstakt tid er med andre ord. to sider af samme sag.

Sokrates' kritik af skriften gik bl.a. på, at den er på afstand af dens egen ophavsmand; den bliver læst i en anden situation end den bliver til i, og læseren og skribenten har som regel ingen anden mulighed for kommunikation end den, "de døde bogstaver" tillader. Samtidig tilbyder tryksagen sig som en anden hore til enhver, der har penge at betale med, og den er på denne måde demokratisk: over for skriften er alle, som vel at bemærke kan læse, lige. Da tryksagen på grund af. mulighederne for masseproduktion samtidig er billig er udbredelsesfrekvensen for de budskaber den indeholder enorm. Sammenholdes dette med de analytiske potentialer, skriften udvikler for tænkningen, da kan denne form for "print-capitalism"16 bestemmes som en aktiv nihilisme. Nihilismebegrebet er hentet fra den tyske filosof Friedrich Nietzsche, der hermed betegner en udvikling i den vesterlandske tænkning, som går ud på, at enhver værdi, ethvert fikseret grundlag for tænkningen problematiseres med det resultat, at der ingen første begrundelse findes for tænkningen eller for etikken. Alt kan gøres til genstand for kritik med den konsekvens, at Den store Mening med tilværelsen fortoner sig i et slags intet (nihil). På den ene side kan dette føre til oplevelse af meningsløshed, ensomhed og fremmedbestemthed, men på den anden side fører det til frisættelse af tænkningen; der er ingen filosofisk eller religiøst bestemte hindringer for udvikling i tænkning, videnskab og teknologi. På den ene side en destruktiv tendens til nedbrydelse af fasttømrede værdisystemer, på den anden side en frisættelse af enorme udviklingspotentialer. Der skal ikke megen fantasi til at se, hvad en liberal holdning til tryksager vil betyde for systemer som 
dem, vi kender fra den islamiske verden, der lader politik og religion være to sider af samme sag.

\section{Romaner}

I sit lille essay "Er Intet Helligt?" skriver Salman Rushdie: "Litteraturen er det eneste sted i noget samfund, hvor man i sit eget hoveds skjul kan høre stemmer, der taler om alting på alle toenkelige måder. Grunden til at sikre, at denne privilegerede arena bevares, er ikke, at forfatterne ønsker absolut frihed til at sige og gøre lige præcis, hvad der passer dem, men derimod, at vi, os alle sammen, læsere og forfattere og borgere og generaler og gudsmennesker, har brug for det lille ubetydeligt udseende rum. Vi behøver ikke kalde det helligt, vi skal bare altid huske på, at det er nødvendigt". ${ }^{17}$ Af konteksten fremgår det, at den litteratur, Rushdie taler om, er romanen, og for egen regning kan det tilføjes, at der ikke er tale om et "lille ubetydeligt udseende rum", men tværtimod, at romanen fremfor noget er det fænomen, som inkarnerer den europæiske civilisation. I sin hyldest til romanen skriver Milan Kundera, at den udgør et "imaginært rum, hvor ingen sidder inde med sandheden, og hvor enhver har ret til at blive forstået. Dette imaginære rum fødtes samtidig med det moderne Europa, det er et billede på Europa, eller i det mindste vor drøm om Europa". ${ }^{18}$

At romanen fødes med det moderne Europa, som Kundera udtrykker det, gør den til noget særligt blandt de litterære genrer: Alle andre genrer kendes såvel før moderniteten som i andre kulturer; det er kun romanen, der er afhængig af bogen og som sådan udviklet som genre efter Gutenbergs opfindelse. Det betyder, at den konflikt mellem det orale og det litterære, som er søgt skildret i det ovenstående inkarneres i romanen, som i modsætning til alle de andre litterære genrer ikke kommer fra en oral tradition og heller aldrig bliver en del af den. Den oplevelse romanen formidler, er individuel, og det fællesskab, den skaber, er formelt og abstrakt. To millioner mennesker kan godt på samme tid læse den samme roman, men de gør det i enrum hver for sig og det eneste, der binder dem sammen, er faktisk en fiktion. At udviklingen af denne fiktion tidsmæssigt falder sammen med udviklingen af et andet moderne fænomen, nemlig nationalstaten er næppe tilfældigt. Som Timothy Brennan skriver i sin bog Salman Rushdie and the Third World (London 1989): "Udviklingen af den moderne nationalstat i Europa er uadskillelig fra udviklingen af former og emner i litteraturen. På den ene side var de politiske emner styrende for litteraturen i retning af romantiske begreber som f.eks. "folkekarakter" og "nationalsprog" til brug ved en inddeling af litteraturen i nationallitteratur. På den anden side og ligeså fundamentalt var litteraturen en del af dannelsen af stater gennem udviklingen af et nationalt trykt medium: avisen og 
romanen". Det er igennem avisen og romanen, at et folk kan få en identitet bl.a. gennem et nationalsprog, der må betegnes som en grafolekt, der laver en standard for det sprog, der skal tales i et bestemt område. Marginaliseringen af dialekterne er et udtryk for, at det er skrift som formel national grafolekt, der bestemmer talen og ikke de lokale sprog. Med andre ord bæres udviklingen eller formningen af en særlig diskurs om det nationale af avisen og romanen.

Lidt sat på spidsen kan romanen siges at være formidleren af den ny tids metafysik, nationalstatsideologien, der overtager tidligere tiders religiøse diskurs om oprindelse, sammenhæng og mål. Folk med forskellige etniske tilhørsforhold, med forskellige sprog (dialekter), med forskellig placering i et socialt og Økonomisk hierarki bringes sammen til ét folk, med ét sprog og med én oprindelse. De lokale og konkrete livsspor slettes til fordel for en formel og abstrakt sammenhæng. Som eksempel herpå kan tages et af de nyeste nationalstatsprojekter i Europa, nemlig Tyrkiet. Eller rettere kan man her tale om en bevidst tilrettelagt europæisering af en mellemøstlig kultur. En proces, der "blev gennemført systematisk som en serie af "revolutioner", hvorigennem alle mulige ydre tegn på orientalsk tilhør blev fjernet. Skriftsproget blev ændret fra arabiske tegn til latinsk alfabet, befolkningen fik fornavne og efternavne efter europæisk skik, klædedragten blev europæiseret, den gregorianske kalender blev indført og vigtigst af alt: politikken blev sækulariseret. Stat og "kirke" blev adskildt, og lovgivningen blev lavet om, således at ethvert spor af sharia er blevet fjernet. Religion er udtrykkeligt en privatsag, selv om $98 \%$ af befolkningen er muslimsk. Derfor er Tyrkiet ikke en muslimsk stat, men en verdslig stat. Problemet er bare, at ikke alle i Tyrkiet billiger denne proces. Kurderne har holdt fast ved deres etniske særpræg og i betydeligt omfang også ved deres sprog, selv om der ikke må undervises i det, og selv om det er forbudt at anvende det på tryk. I mange år nægtede myndighederne simpelthen, at der eksisterede et kurdisk sprog. De påstod, at kurdisk bare var en afart af tyrkisk, og betegnede kurderne som bjergtyrkere. Nu er det blevet lidt bedre. Præsident Özal tillod under Kuwaitkrigen, at kurdisk blev talt og sunget, men det er stadig ikke tilladt på tryk, og det anvendes heller ikke i radio eller TV. Eftersom regeringen officielt benægter eksistensen af alvorlige etniske modsætninger, er det vanskeligt at få pålidelige oplysninger om deres omfang, og antallet af kurdere er stærkt omdiskuteret med angivelser, der varierer mellem 2 og 20 mill. Et gæt på et tal midt i mellem (8 - 10 mill.) vil næppe være helt ved siden af". ${ }^{19}$ Tyrkiet har villet gennemgå en proces på et halvt århundrede, som i Europa tog flere århundreder - og det giver selvfølgelig problemer. Ikke desto mindre er præmisserne klare: ét fælles sprog, én fælles national identitet, én fælles tid, sækularisering og afpolitisering af religionen. Hvor meget man så end skal lægge i det, så er det i denne sammenhæng svært at undgå at bemærke, at europæiseringen også medførte en overgang til det latinske alfabet.

I Europa var romanen, som nævnt, i høj grad med til at bære denne udvikling 
sammen med avisen. Ikke sådan at forstå, at romanen og hele industrien omkring den - de første forfattere, der kunne tjene penge ved at markedsføre deres vare, var romanforfattere - er primus motor i udviklingen; det ville være at tilkende den for stor en rolle i historiens forløb, men den var et overmåde vigtigt led i iscenesættelsen af diskursen om det nationale og i forbindelse hermed i dannelsen af et "publikum". En yderst abstrakt størrelse, der ikke har andet til fælles, end at medlemmerne taler samme sprog, bor inden for de samme grænser, og alle kan læse. Som Ong udtrykker det: "The writer's audience is always a fiction". Principielt og ideelt set er publikum imidlertid andet end en anonym skare af læsere; det er også stedet, hvor nye tanker kan formidles, hvor spørgsmålstegn ved de gængse meninger kan sættes, hvor, som Rushdie siger det, "man kan høre stemmer tale om alle mulige ting på alle tænkelige måder". Den første litteratur, der får et publikum, et marked, er romanen, og det er stadigvæk den form for litteratur, der er flest penge i og dermed lettest når størst udbredelse. Romanen er således som tankens laboratorium og markeds$\emptyset$ konomiens duks hinsides godt og ondt en stærk metafor for "print-capitalism" civilisation. Som et rent produkt af "print-capitalism" må romanen for systemer og kulturer som de mellemøstlige, der søger at fastholde en magtfuld integration af moral, religion og politik, tage sig ud som en kræftsvulst, hvis udbredelse kun kan stoppes med bål og brand. For en vesterlænding, der har haft liberal omgang med romaner, siden han trådte sine barnesko, kan den muslimske verdens reaktion mod Rushdies bog både virke chokerende og som at skyde gråspurve med kanoner. Jeg vil påstå, at det netop er fordi, at De sataniske vers er en roman, at reaktionen kunne blive så stærk: En roman, der stiller pinlige spørgsmål til religionen, er langt mere farlig, både på grund af dens potentielle store publikum og fordi den inkarnerer en hel kultur, den vestlige civilisation, end nok så mange digte og videnskabelige essays; de sidste kunne nok påkalde sig censur og vrede, men næppe mord, dødsdomme og afbrudte diplomatiske forbindelser.

\section{Religion og politisk iscenesættelse}

Når det er slået fast, at en væsentlig betingelse for Rushdieaffærens omfang skyldes det simple faktum, at der er tale om en roman, så er der dermed selvfølgelig ikke samtidig sagt, at dette alene kan gøre det. Andre betingelser som indholdet i bogen, sammenfald af sociologiske, politiske og andre omstændigheder skal også være tilstede - og det var de.

Udgivelsen af bogen den 26. september 1988 faldt sammen med et nært forestående valg i Indien, og Rajiv Gandhis Kongresparti havde brug for de muslimske vælgeres stemmer. Dens fordømmelse allerede den 5. oktober skal ses i denne sammenhæng, og Rushdie reagerede selv hurtigt i et brev til Gandhi, hvor han om 
oppostionsledere sagde: "they really don't care about my novel one way or the other. The real issue is, who is to get the Muslim vote".

I Pakistan kunne de muslimske fundamentalister ikke lade chancen gå fra sig til at udnytte anti-Rushdie bevægelserne til at ryste Benazir Bhuttos nye styre. Og det var også en penibel situation for hende som leder af den første demokratiske regering i ti år at skulle forbyde bogen.

I England havde forholdet mellem de muslimske indvandrere og de indfødte englændere længe været spændt. Muslimernes arbejdsløshed var høj, de var særligt ramt af en omlægning i skattepolitikken, i modsætning til andre mindretal som f.eks. jøder og katolikker havde de ingen ret til egne skoler, feministernes kritik af 3. verdens familiemønstre rettede sig kun mod muslimer, og blasfemiparagraffen i den engelske lov omhandler kun kristendom. Forsøg fra muslimsk side på at råbe politikere op og andre tiltag i retning at få forbedret vilkårerne var ikke blot slået fejl, men var i almindelighed blevet systematisk ignoreret. Utilfredsheden blandt muslimer var og er derfor stor og manifest især i de områder, hvor der er mange samlet, således i Bradford. Mere moderate protester mod Rushdie i starten udviklede sig hurtigt til radikale krav om tilbagetrækning af romanen samt økonomisk kompensation til islamisk velgørenhed. Den 14. januar 1989 var verden vidne til bogafbrændningerne i Bradford, og i medierne blev de voldsomme demonstrationer fremstillet som spontane handlinger fra dogmatiske muslimer. I virkeligheden var der tale om et veltilrettelagt forløb, hvor først sider fra bogen var blevet fotokopieret og uddelt, dernæst en demonstration indkaldt, hvor man selvfølgelig havde sørget for at briefe medierne, så de kunne være tilstede. Men det var nok mere social indignation end sårethed over en bog, ingen havde læst, der kom til udtryk ved den og ved andre lejligheder. "In other words, the political arena in Britain is a fascinating and serious one, but the relationship to Rushdie's novel to it has more to do with the social relations beyond the text than with the content of the text". ${ }^{20}$

Iranerne var sene til at komme med et udspil - til gengæld med nok så megen effekt. Det berømte og utilstedelige fatwa blev udstedt af Khomieni den 14. februar 1989. I det krigshærgede Iran var den islamiske revolution på dette tidspunkt ved at køre på lavblus og kræfter i landet havde gjort tiltag til at normalisere det spændte forhold til vesten. Med sit fatwa fik Khomeini igen sat fokus på islam og det dekadente vesten og fik hindret enhver normaliseringsproces - i det mindste for en tid. At Rushdie-sagen i Iran mere var en politisk konflikt, end den skyldtes religion, understøttes også af, at bogen faktisk blev anmeldt i landet, uden at dette gav anledning til videre bekymring, samt at Rushdies tidligere romaner Skam og Midnatsbørn ikke blot var kendte og oversatte til persisk: Skam havde faktisk modtaget en pris som den bedst oversatte roman, som var blevet uddelt af den daværende præsident og nuværende religiøse overhovede Ali Khamenei. Med andre ord vil en forståelse af Rushdieaffæren, der tager udsagnene om religiøs krænkethed 
og blasfemi for pålydende fejlvurdere sagen. Der er meget mere end religion på spil: For de muslimske lande handler det om for alt i verden ikke at tillade fri tænkning; ikke af religiøse grunde, men af magtpolitiske. For de vestlige lande handler det ikke om, at vi står over for nogle islamiske styrer, for hvem det er altafgørende at beskytte islam og troen mod krænkelser; det handler om statscentralistiske, paramilitære styrer, der iklæder den politiske diskurs en religiøs retorik. Dette kan de slippe afsted med, så længe den almindelige muslim holdes uden for politisk indflydelse, og det kan de så lang tid, det lykkes dem at holde skriften uden for samfundet.

\section{En stakket frist}

Imidlertid sker der også forandringer i de mellemøstlige lande. Modernitetsfænomener viser sig også her. Paradoksalt nok var Rushdieaffæren aldrig blevet til noget, hvis det ikke havde været for moderne typografiske og elektroniske mediers skyld. Det samme kan man sige om Khomeinis revolution i Iran. Her var det ikke nok med moskeerne til at bringe budskabet ud; man havde stor hjælp af kasette- og videobånd.

At der er ved ske noget på den politiske front i Mellemøsten, er fundamentalismen på flere måder et vidnedsbyrd om. Fundamentalisme kan for en lidt hurtig betragtning godt se ud som en regressiv nostalgist bølge, der går igennem de mest vesternaliserede lande, som f.eks. Tunesien, Algeriet, Ægypten. Faktisk tror jeg, at der her er tale om et modernitetsfænomen, altså om en politisk-religiøs strømning, som først er blevet mulig i og med typografiske og elektroniske medier, urbanitet, uddannelse og udvikling af en form for politisk kultur, der i det mindste ligner den vestlige.

Generelt er indholdet i de fundamentalistiske programmer ligeså abstrakt, som det er stereotypt: på den ene side en bredside mod vesten som udspredende dekadente og destruktive tanker og ideer, på den anden side en insistering på traditionelle islamiske værdier som kønsadskillelse og tilsløring af kvindekroppen, forbud mod alkohol, for arabisk enhed og indførelse af islamisk principper i økonomien, f.eks. ingen skat og ingen renter. På nær det med den arabiske enhed var det programmet i Iran, det er programmet for FIS, og det er programmet for de forskellige bevægelser i ÆEgypten. I Iran lever den islamiske republik stadig, men problemerne er alt andet lige store, hvilket landets amplitudiske bevægelser i holdningen til det vestlige marked demonstrerer. Med hensyn til. Algeriet og Ægypten gør det faktum sig gældende, at vi her står over for lande med voldsomme økonomiske, befolkningsmæssige og styringsmæssige problemer. For begge landes vedkommende er ressourcerne små og behovene store: mangel på boliger, arbejde og fødevarer er gået 
hånd i hånd med en stadig mere uduelig, centralistisk og bureaukratisk politik. Der er forskelle de to lande i mellem: ÆEgypten har på grund af. sin strategiske beliggenhed og gennem den åbenhed over for Vesten, som Sadat indledte, haft større held med at redde sig nogle mia. \$ udefra end Algeriet, der i al for lang tid har forsøgt sig med et "østeuropæisk"-lignende system. De fundamentalistiske oprør ligner dog i mønster hinanden: Det er storbyfænomener, de aktive rekrutteres mest blandt unge, der kommer fra familier på landet, som både har haft råd til og givet datteren eller sønnen mulighed for at studere i byen, ofte på de teknisk-naturvidenskabelige fakulteter. Deres forståelse af islam er en anden end den gængse "folkereligion"; en forståelse, som kræver refleksion og en vis form for belæsthed og budskaberne cirkuleres gennem personlig kontakt, men også gennem tryksager. De, der organiserer og formidler det fundamentalistiske islamiske budskab, er samtidig dem - kan man antage som hypotese - der principielt set formidler en civilisering eller samfundsmæssiggørelse, forstået som etableringen af en politisk offentlighed. De, der i Algeriet formidler budskabet "Død over Vesten, død over USA", er samtidig dem, der mest hårdnakket har insisteret på demokratiske valg. Islam er her også en politisk retorik, hvorigennem utilfredshed over urimelige levevilkår og vrede over et impotent styre kan komme til orde, og det er nok ikke sikkert, at demokratiet ville få lov at bestå meget længere end et veloverstået valg. Pointen er her ikke at gøre de islamiske fundamentalister til heroiske forkæmpere for demokrati - langt fra, men at gøre opmærksom på, at den kamp de fører, kun er mulig takket være modernitet. Måske kan det være, at sociologen Max Webers tese om gennemførelsen af det sækulariserede moderne vestlige samfund gennem en kristen fundamentalisme i bogen Kapitalismens and og protestantismens etik er ved at gentage sig her. De islamiske lande har ikke haft en feulalisme som vi kender den fra Europa, og det er derfor forkert, at betegne Mellemøsten som "mørk middelalder". Alligevel synes der at være træk, vi kan genkende fra europæisk historie: For det første, at der er en paradoksal sammenhæng mellem fundamentalisme og modernitet, og for det andet, at konflikterne om læsning - faktisk er der islamiske intellektuelle, der har udtrykt støtte til Rushdie og peget på, at han som muslim står i en islamisk satirisk tradition i den islamiske verden på mange måder ligner de kampe, som blev udspillet i det 18 . og 19. århundredes England omkring det hensigtsmæssige i, at arbejdere og (i Amerika) slaver skulle lære at læse. Under alle omstændigheder er det udtryk for orientalisme forstået som romantisering eller dæmonisering af Mellemøsten at tage såvel harmen over Rushdie som de fundamentalistiske bevægelsers religiøse retorik på ordet og ignorere det politiske indhold.

Som Ümit Necef ${ }^{21}$ har vist, var det imidlertid dét, mange velmenende danskere gjorde i forbindelse med Rushdiedebatten i Danmark: af frygt for at være usolidariske med de fremmede, "de Andre", undlod man at tage stilling bl.a. med den begrundelse, at man jo dog må respektere andre kulturer. Man faldt ind i en 
fortælling eller en diskurs, der straks identificerede den islamiske krænkethed som et respektabelt ydtryk for en anden kultur, hvis værdier man ikke kan andet end tillade sig at acceptere. Dette synspunkt er imidlertid dobbelt dumt: for det første respekterer man derigennem ikke andre kulturer, men bekræfter kun sin egen - i denne sammenhæng overreflekterede kultur; for det andet prisgives dermed dén tankens frihed, det er at kunne skrive litteratur, hvilket ifølge såvel Rushdie som Kundera ikke er et helt ubetydeligt rum for Europa - snarere tværimod: "Express your self", som Madonna synger.

1. Mohammad T. Mehdi, Islam and Intolerance. A reply to Salman Rushdie.

( New York 1990). Malise Ruthven, A Satanic Affair. Salman Rushdie and Rage Rage og Islam (London 1990).

2. Timothy Brennan henviser i bogen Salman Rushdie \& and the Third World (London 1989) s. 143 f.eks. til den pakistanske digter Muhammad Iqbal, der her angiveligt taler om gud som en hore.

3. Jeg har læst den amerikanske udgave: Michel Foucault, The Order of Things. An Archaelogy of the Human Sciences (New York 1970).

4. Edward W. Said, Orientalism (New York 1978).

5. Hegelcitatet er hentet hos Jacques Derrida, Om grammatologi (København 1970) s. 74.

6. Salman Rushdie, I god tro \& Er Intet helligt? (København 1990) s. 9.

7. Salman Rushdie, De sataniske vers (SV) (København 1988) s. 172f og The Satanic Verses (London 1988) s.157f.

8. I god tro, op.cit.

9. Her citeret fra Julia Kristeva, The Kristeva reader. Udgivet af Toril Moi (Oxford 1986)

10. SV s.13/3.

11. Platon citeres her fra Lars Erslev Andersen, Allegori og Mimesis. Platon - Benjamin tur/retur (Århus 1989) s. 52f. I bogen analyserer jeg bl.a. forholdet mellem tale og skrift hos Platon. Baggrunden for de følgende betragtninger er herudover Søren Mørch, Civilisationen (København 1991), der netop karakteriserer det europæiske som skriftlighed. Bogen er 1. bind i 6 binds værket Det Europæiske Hus under redaktion af Søren Mørch.

12. Lund, Erik, De europæeiske ideers historie. Af Erik Lund, Mogens Pihl og Johannes Sløk (København 1962) s.

13. Mørch, op.cit. s. 61.

14. Ong s.51f.

15. ibid. s.43f.

16. Med termen vil jeg henvise til en anden inspirationskilde, nemlig Benedict Anderson, Imagined Communities. Reflections on the Origin and Spread of Nationalism (revideret udgave: London 1991).

17. op.cit. s. 64.

18. Milan Kundera, Romankunsten (København 1987) s. 170. 
19. Søren Mørch i "Landeprofil: Tyrkiet" i Mellemøst-Information februar 1992. 20. Michael M. J. Fischer \& Mehdi Abedi, Debating Muslims. Cultural Dialoues in Postmodernity and Tradition (London 1990) s. 396. Meget materiale og dokumentation vedrørende Rushdiesagen er iøvrigt samlet i Lisa Appignanesi \& Sara Maitland, The Rushdie File (London 1989).

21. Se Ümit Necef fine fremstilling i artiklen "Rushdie-debatten, indvandrerforskerne og indvandrerne" i antologien Islam. 